\title{
Benzyladenine and Gibberellic Acid Application Prevents Abscisic Acid-induced Leaf Chlorosis in Pansy and Viola
}

\author{
Nicole L. Waterland ${ }^{1}$, John J. Finer, and Michelle L. Jones ${ }^{2}$ \\ Department of Horticulture and Crop Science, The Ohio Agricultural \\ Research and Development Center, The Ohio State University, 1680 Madison \\ Avenue, Wooster, OH 44691
}

Additional index words. ABA, bedding plants, drought, floriculture, postproduction, Viola cornuta, Viola $\times$ wittrockiana

\begin{abstract}
Drought stress during the shipping and retailing of floriculture crops can reduce postproduction shelf life and marketability. The plant hormone abscisic acid (ABA) mediates drought stress responses by closing stomata and reducing water loss. Applications of exogenous s-ABA effectively reduce water loss and allow a variety of species to survive temporary periods of drought stress. Unfortunately, s-ABA application can also lead to leaf chlorosis, which reduces the overall quality of economically important bedding plant species, including Viola $\times$ wittrockiana (pansy). The goal of this research was to determine how to prevent $\mathbf{s - A B A - i n d u c e d ~ l e a f ~ c h l o r o s i s ~ i n ~ p a n s y ~ a n d ~}$ a closely related species, Viola cornuta (viola). All concentrations of both spray (250 or $\left.500 \mathrm{mg} \cdot \mathrm{L}^{-1}\right)$ and drench $\left(125 \mathrm{or} 250 \mathrm{mg} \cdot \mathrm{L}^{-1}\right) \mathrm{s}-\mathrm{ABA}$ applications induced leaf yellowing. Young plants at the plug stage and 11-cm finished plants with one to two open flowers were further evaluated to determine if the developmental stage of the plants influenced s-ABA effectiveness or the development of negative side effects. Both plugs and finished pansies and violas developed leaf chlorosis after s-ABA applications, but symptoms were generally more severe in finished plants. The individual application of benzyladenine (BA), gibberellic acid $\left(\mathbf{G A}_{4+7}\right)$, or the ethylene perception inhibitor, 1-methylcyclopropene, before s-ABA application had no effect on the development of s-ABA-induced leaf chlorosis. However, applications of 5 or $10 \mathrm{mg} \cdot \mathrm{L}^{-1} \mathbf{B A}$ and $\mathrm{GA}_{4+7}$ as a mixture $(\mathrm{BA}+$ $\left.\mathbf{G A}_{4+7}\right)$ before a drench or spray application of s-ABA prevented leaf chlorosis. The application of $\mathrm{s}-\mathrm{ABA}$ and $\mathrm{BA}+\mathbf{G A}_{4+7}$ would allow floriculture crops to tolerate temporary periods of drought stress without any loss of postproduction quality.
\end{abstract}

Floriculture crops may encounter harsh environmental conditions during shipping and while on display in retail stores. These

\footnotetext{
Received for publication 21 Jan. 2010. Accepted for publication 19 Apr. 2010.

This research was funded by the OSU D.C. Kiplinger Floriculture Endowment, the Valent BioSciences Corporation, and the Gladys Wittmeyer Knox-Gene Wittmeyer Scholarship. Salaries and research support were provided in part by State and Federal funds appropriated to the Ohio Agricultural Research and Development Center, The Ohio State University. Journal Article Number HCS 10-01.

We thank Green Circle Growers Inc. and Bob's Market for their donation of plant material and Valent BioSciences for donation of plant growth regulators.

The information in this publication is for educational purposes only. Mention of a trademark, proprietary product, or vendor does not constitute a guarantee or warranty of the product nor does it imply approval or disapproval to the exclusion of other products or vendors that may also be suitable. ${ }^{1}$ Current address: Division of Plant and Soil Sciences, West Virginia University, Morgantown, WV 26506. ${ }^{2}$ To whom reprint requests should be addressed; e-mail jones.1968@osu.edu.
}

poor postproduction environments can result in losses of $5 \%$ to $20 \%$ (Armitage, 1993; Healy, 2009). A major cause of postproduction decline is drought stress resulting from infrequent or inconsistent watering (Barrett and Campbell, 2006). Plants respond to water deficit by closing their stomata and decreasing transpirational water loss. This drought stress response is regulated by the plant hormone abscisic acid (ABA) (Malladi and Burns, 2007).

The exogenous application of $\mathrm{ABA}$ or ABA analogs delays drought stress-induced wilting in a variety of bedding and potted plants (Blanchard et al., 2007; Kim and van Iersel, 2008; Monteiro et al., 2001; Sharma et al., 2005, 2006; Waterland et al., 2010). Although ABA applications allow plants to survive temporary periods of drought stress, negative side effects, including leaf necrosis, chlorosis, or abscission, have been observed in some species (Blanchard et al., 2007; Kim and van Iersel, 2008; Waterland et al., 2010). We observed leaf chlorosis on droughtstressed Tagetes patula (marigolds), Pelargonium $\times$ hortorum (seed geraniums), and pansies treated with drench or spray applications of s-ABA. Leaf chlorosis in pansies was not directly induced by drought treatment, because symptoms were observed in both watered and drought-stressed plants that were treated with s-ABA (Waterland et al., 2010). It is unclear why s-ABA induced leaf chlorosis and senescence in pansies or how this side effect might be prevented.

ABA is the main plant hormone associated with drought stress, but most stress responses are the result of cross-talk between hormone signaling pathways (Huang et al., 2008). Although the application of a plant hormone may result in a specific response, these applications can also modify the synthesis and perception of other hormones. The resulting hormone modifications or the interactions between multiple hormones may cause the observed response. To understand a plant's response to an exogenous hormone application, it is therefore necessary to understand these potential hormone interactions. In most cases, drought stress results in an increase in the synthesis of ABA and ethylene and a decrease in the synthesis of auxin, gibberellins, and cytokinins (Nilsen and Orcutte, 1996). ABA applications enhance leaf senescence and abscission by increasing ethylene production and/or increasing ethylene sensitivity (Zacarias and Reid, 1990). Under severe and moderate drought stress, Petunia $\times$ hybrida (petunia) show an increase in ethylene production as well as an increase in S-ABA, the biologically active form of ABA (Vardi and Mayak, 1989). Changes in the balance of ABA, ethylene, gibberellins, and cytokinins within the plant may be responsible for the development of leaf senescence (Blanchard et al., 2007; Waterland et al., 2010) and leaf abscission (Kim and van Iersel, 2008) after s-ABA applications.

The application of other plant hormones, including cytokinins and gibberellins, or the inhibition of ethylene perception may provide a means of preventing ABA-induced leaf chlorosis and abscission. Ethylene perception inhibitors such as 1-methylcyclopropene (1-MCP) have been used to prevent senescence and abscission in a variety of floriculture crops, including cut flowers and potted flowering plants (Blankenship and Dole, 2003). Cytokinins reduce leaf yellowing and senescence by delaying chlorophyll degradation (Gan and Amasino, 1995, 1997). Transgenic petunia and Nicotiana tabacum (tobacco) plants that overproduce cytokinins show delayed leaf senescence and reduced symptoms of leaf chlorosis after drought stress (Clark et al., 2004; Gan and Amasino, 1995). In some species, the application of gibberellic acids (specifically $\mathrm{GA}_{4+7}$ ) reduces postproduction losses by preventing leaf senescence (Han, 1997; Ranwala et al., 2003; Ranwala and Miller, 1998). Even the use of cytokinins and gibberellins in combination is effective at reducing leaf chlorosis in a variety of floriculture crops (Funnell and Heins, 1998; Han, 2001; Kim and Miller, 2009; Ranwala et al., 2000). It is not known why senescence is prevented or delayed in some species by cytokinins and in others by gibberellins nor is it possible to predict which 
species will respond to a particular hormone or combination with delayed senescence. Plant responses to plant growth regulators (PGRs) are highly variable; therefore, all PGRs must be examined in different species, cultivars, and even at various developmental stages before useful recommendations can be developed (Gent and McAvoy, 2000).

The goal of this research was to determine how to prevent s-ABA-induced leaf chlorosis in pansy and viola. Although s-ABA applications allow pansies to survive temporary periods of drought stress, negative side effects like leaf chlorosis decrease overall crop quality (Waterland et al., 2010). Our specific objectives were 1) to determine if cultivar, developmental stage, method of application, and concentration influence the effectiveness of s-ABA and the occurrence of leaf chlorosis symptoms; 2) to identify an application method and/or concentration of s-ABA that would not induce leaf chlorosis; and 3 ) to determine whether s-ABA-induced leaf chlorosis can be prevented by the application of other PGRs, including cytokinins, gibberellins, or ethylene perception inhibitors.

\section{Materials and Methods}

\section{Plant material}

Viola $\times$ wittrockiana (pansy) 'Dynamite Purple' (Kieft-Pro-Seeds), 'Karma Rose Fire' (Goldsmith Seeds), or 'Matrix Blue Frost' (PanAmerican Seed) and Viola cornuta (viola) 'Penny Deep Blue' (Goldsmith Seeds), 'Skippy Lavender' (Kieft-Pro-Seeds), 'Sorbet Yellow Delight', or 'Sorbet Babyface Purple' (PanAmerican Seed) were used in the experiments as described subsequently. Plugs (young plants in the vegetative stage) were obtained from Green Circle Growers Inc. (Oberlin, OH) or Bob's Market (Mason, WV). Cell packs $\left(1204 \mathrm{~s} ; 96.1 \mathrm{~cm}^{3} /\right.$ cell) of viola 'Sorbet Babyface Purple' and pansy 'Matrix Blue Frost' were obtained from Green Valley Growers Inc. (Ashland, $\mathrm{OH}$ ) for all finished plant experiments (Expts. 1 and 2).

Expt. 1: s-abscisic acid treatment of 11-cm finished pansies and violas. Pansy 'Dynamite Purple', 'Karma Rose Fire', and 'Matrix Blue Frost' and viola 'Penny Deep Blue', 'Skippy Lavender', and 'Sorbet Babyface Purple' plugs or cell packs were transplanted to $11-\mathrm{cm}$ pots with soilless greenhouse media (Pro-Mix-BX-Mycorise-Pro ${ }^{\circledR}$; Premier Horticulture, Quebec, Canada). Plants were grown under natural irradiance with supplemental lighting provided as needed by high-pressure sodium and metal halide lamps (GLX/GLS esystems GROW lights; PARSource, Petaluma, CA). The average photosynthetic photon flux $(P P F)$ was $330 \mu \mathrm{mol} \cdot \mathrm{m}^{-2} \cdot \mathrm{s}^{-1}$ from 0700 to $1900 \mathrm{HR}$ daily [mean daily light integral $\left.(\mathrm{DLI})=18.4 \mathrm{~mol} \cdot \mathrm{m}^{-2} \cdot \mathrm{d}^{-1}\right]$. Mean greenhouse temperatures were $22.4 / 15.8{ }^{\circ} \mathrm{C} \pm 2.0 / 1.6$ day/night with daytime relative humidity of $51.6 \% \pm 7.5 \%$. Plants were irrigated daily with $200 \mathrm{mg} \mathrm{N} / \mathrm{L}$ Peters Excel ${ }^{\circledR}$ Cal-Mag $15 \mathrm{~N}$ 2.15P-12.5K (Scotts-Sierra Horticulture Products, Marysville, $\mathrm{OH}$ ), which was reduced to $100 \mathrm{mg}$ N/L 2 weeks before flowering. s-ABA treatments were applied to finished pansies and violas when they reached a marketable stage of one to two open flowers per plant and the foliage and roots had reached the edge of the pot. Applications were on 26 Apr. 2008 for pansy 'Matrix Blue Frost' and viola 'Sorbet Babyface Purple' and 6 May 2008 for the other four cultivars. All plants were watered to container capacity $12 \mathrm{~h}$ before s-ABA (ConTego $^{\text {TM }}$; Valent BioSciences Corp., Libertyville, IL) application. s-ABA was applied according to manufacturer's recommendations as a drench at 0,125 , or $250 \mathrm{mg} \cdot \mathrm{L}^{-1}(60 \mathrm{ml}$ per container $)$ or as a spray at 0,250 , or $500 \mathrm{mg} \cdot \mathrm{L}^{-1}$ $(\approx 6.6 \mathrm{~mL}$ per plant $)$ with the addition of $0.05 \% \mathrm{CapSil}^{\circledR}$ (Aquatrols Corporation of America, Inc., Cherry Hill, NJ). Spray applications were applied with a Regulator Bakpak $^{\circledR}$ sprayer (H.D. Hudson Manufacturing Company, Chicago, IL). Half of the plants from each treatment were irrigated daily with $100 \mathrm{mg} \mathrm{N} / \mathrm{L}$. The other half (i.e., droughtstressed) had water withheld until the s-ABAtreated plants wilted and then they were
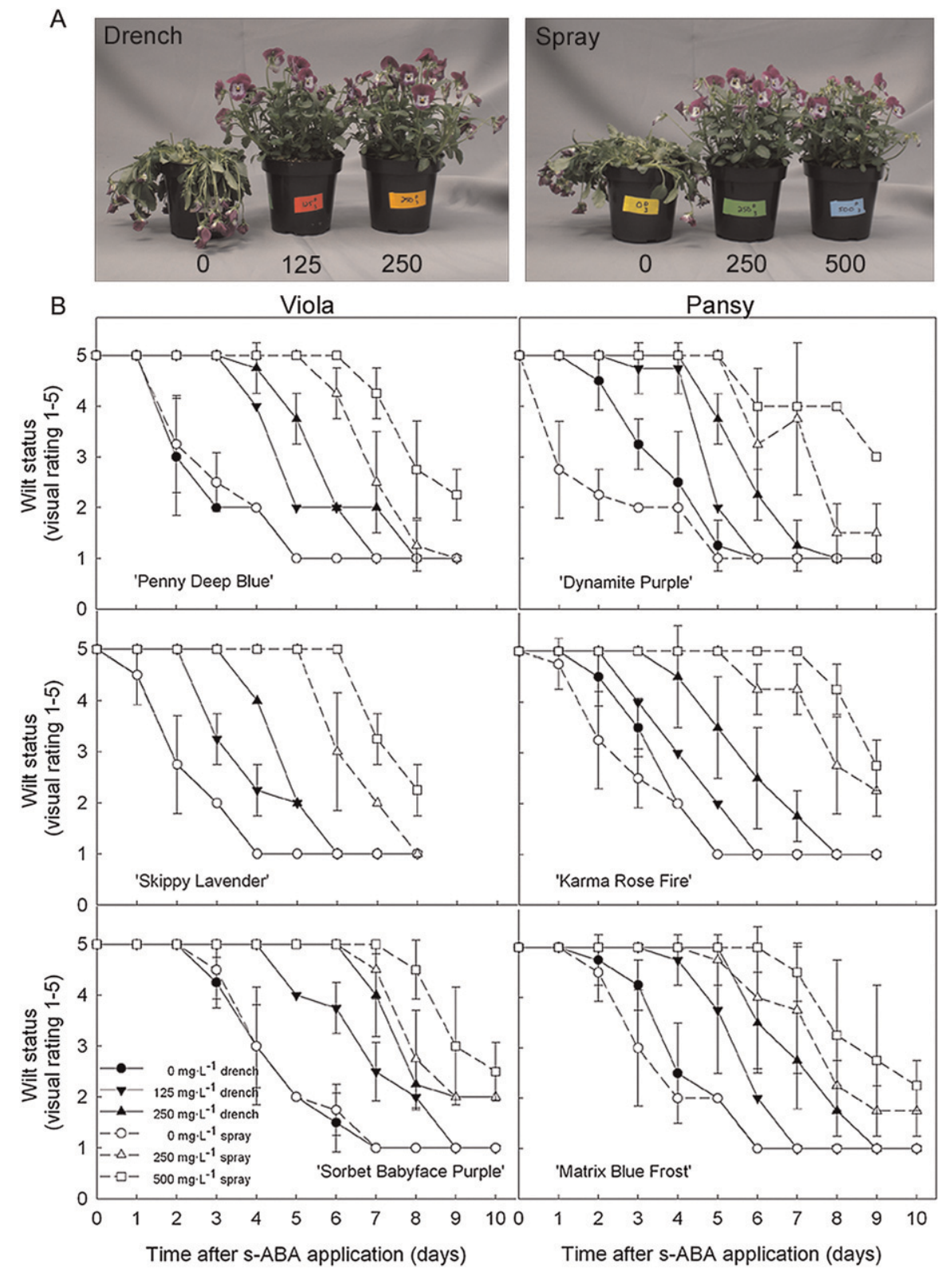

Fig. 1. Visual symptoms of wilting and daily wilt status ratings of $11-\mathrm{cm}$ finished Viola cornuta (viola) and Viola $\times$ wittrockiana (pansy) after withholding water. Images are of viola 'Sorbet Babyface Purple' $5 \mathrm{~d}$ after the application of s-abscisic acid (s-ABA) and subsequent drought stress (A). The left image is of drench applications of 0,125 , and $250 \mathrm{mg} \cdot \mathrm{L}^{-1} \mathrm{~s}-\mathrm{ABA}$ and the right image is of spray applications of 0,250 , and $500 \mathrm{mg} \cdot \mathrm{L}^{-1} \mathrm{~s}-\mathrm{ABA}(\mathbf{A})$. Water was withheld until s-ABA-treated plants were wilted (wilt status rating of 3 or below), and wilt status ratings were determined daily (B). Day 0 observations were taken just before ( 1 to $2 \mathrm{~h}$ ) s-ABA application and withholding of water. Wilt status ratings were from 1 to $5: 5=$ completely turgid, $4=$ soft to touch but still upright, $3=$ starting to wilt and no longer upright, $2=$ wilted with complete loss of turgor, and $1=$ wilted to the point that leaves are dry and desiccated. Values are means \pm SD of four replications $(n=4)$. 


\begin{tabular}{|c|c|c|c|c|c|c|}
\hline \multirow[b]{3}{*}{ Species and cultivar } & \multicolumn{6}{|c|}{ Application method and s-ABA concn $\left(\mathrm{mg} \cdot \mathrm{L}^{-1}\right)$} \\
\hline & \multicolumn{6}{|c|}{ Time until visually wilted (days) } \\
\hline & 0 & 125 & 250 & 0 & 250 & 500 \\
\hline Penny Deep Blue & $2.5 \mathrm{~d}$ & $5.0 \mathrm{c}$ & $5.8 \mathrm{c}$ & $2.5 \mathrm{~d}$ & $7.3 \mathrm{~b}$ & $8.3 \mathrm{a}$ \\
\hline Skippy Lavender & $2.3 \mathrm{e}$ & $3.3 \mathrm{~d}$ & $5.0 \mathrm{c}$ & $2.3 \mathrm{e}$ & $6.5 \mathrm{~b}$ & $7.3 \mathrm{a}$ \\
\hline Sorbet Babyface Purple & $4.5 \mathrm{~d}$ & $6.8 \mathrm{c}$ & $7.8 \mathrm{~b}$ & $4.3 \mathrm{~d}$ & $8.3 \mathrm{~b}$ & $9.5 \mathrm{a}$ \\
\hline \multicolumn{7}{|l|}{ Viola $\times$ wittrockiana } \\
\hline Matrix Blue Frost & $4.3 \mathrm{~d}$ & $5.8 \mathrm{c}$ & $7.0 \mathrm{~b}$ & $3.5 \mathrm{~d}$ & $7.5 \mathrm{~b}$ & $8.8 \mathrm{a}$ \\
\hline
\end{tabular}

${ }^{2}$ Values are means of four replications $(\mathrm{n}=4)$. Values in rows followed by different letters are statistically different at $P \leq 0.05$ (least significant difference test). Shelf life is the average number of days from Day 0 that it took each plant to show visible symptoms of wilt. This is equivalent to a rating of 3 (starting to wilt) or less on the wilt status rating scale of 1 to 5 in which $5=$ completely turgid, $4=$ soft to touch but still upright, $3=$ starting to wilt and no longer upright, $2=$ wilted with complete loss of turgor, and $1=$ wilted to the point that leaves are dry and desiccated. Shelf life extension is the number of additional days from the time in which the control plants wilted until the s-ABA-treated plants wilted.

$\mathrm{s}-\mathrm{ABA}=$ abscisic acid.

rewatered. Plants were held in the greenhouse under the environmental conditions described previously for all subsequent evaluations.

Expt. 2: Plant growth regulator applications to 11-cm finished pansies and violas. PGRs were applied to $11-\mathrm{cm}$ finished pansy 'Matrix Blue Frost' and viola 'Sorbet Babyface Purple' before s-ABA application. Cell packs were transplanted and plants were grown in the greenhouse as described previously. Treatments for Expt. 2A began on 13 May 2008. Average $P P F$ was 340 $\mu \mathrm{mol} \cdot \mathrm{m}^{-2} \cdot \mathrm{s}^{-1}$ from 0500 to $1900 \mathrm{HR}$ daily $(\mathrm{DLI}=17.6)$. Mean greenhouse temperatures were $22 / 15{ }^{\circ} \mathrm{C} \pm 2.1 / 0.9$ day/night with daytime relative humidity of $51.2 \pm 5.6 \%$. PGR treatments included spray applications $(\approx 4.4 \mathrm{~mL}$ per plant) of benzyladenine (BA) (MaxCel ${ }^{\circledR}$; Valent BioSciences Corp.), $\mathrm{GA}_{4+7}$ (ProVide ${ }^{\circledR}$; Valent BioSciences Corp.), or $\mathrm{BA}+\mathrm{GA}_{4+7}$ (Promalin ${ }^{\circledR} /$ Fascination $^{\circledR}$; Valent BioSciences Corp.) were applied at the rates of $0,1,2,5$. or $10 \mathrm{mg} \cdot \mathrm{L}^{-1}$ (plus $\left.0.05 \% \mathrm{CapSil}^{\circledR}\right) 12 \mathrm{~h}$ before 0 or $250 \mathrm{mg} \cdot \mathrm{L}^{-1}$ s-ABA. Treatments also included 1-MCP (EthylBloc ${ }^{\circledR}$; Floralife ${ }^{\circledR}$, Inc., Walterboro, SC), an ethylene perception inhibitor, at the manufacturer's recommended rate of $300 \mathrm{~nL} \cdot \mathrm{L}^{-1}$ for $10 \mathrm{~h}$ before a drench application of 0 or $250 \mathrm{mg} \cdot \mathrm{L}^{-1} \mathrm{~s}-\mathrm{ABA}$. All plants in this experiment were irrigated daily with $100 \mathrm{mg} \mathrm{N} / \mathrm{L}$.

Based on the observations from the first PGR experiment outlined previously (Expt. $2 \mathrm{~A}$ ), a concentration of $5 \mathrm{mg} \cdot \mathrm{L}^{-1} \mathrm{BA}+\mathrm{GA}_{4+7}$ was selected for the treatment of all six pansy and viola cultivars in Expt. 2B. Treatments began on 13 June 2008 under the greenhouse conditions described previously. Average $P P F$ was $359 \mu \mathrm{mol} \cdot \mathrm{m}^{-2} \cdot \mathrm{s}^{-1}$ from 0500 to 1900 HR daily $(\mathrm{DLI}=19.8)$. Mean greenhouse temperatures were $24.3 / 18^{\circ} \mathrm{C} \pm$ $3.0 / 2.5$ day/night with daytime relative humidity of $60.9 \pm 8.7 \%$. BA $+\mathrm{GA}_{4+7}$ at 0 or $5 \mathrm{mg} \cdot \mathrm{L}^{-1}$ (plus $0.05 \% \mathrm{CapSil}^{\circledR}$ ) was applied $12 \mathrm{~h}$ before either a drench application of 0 or $250 \mathrm{mg} \cdot \mathrm{L}^{-1} \mathrm{~s}-\mathrm{ABA}$ or a spray application of 0 or $500 \mathrm{mg} \cdot \mathrm{L}^{-1} \mathrm{~s}-\mathrm{ABA}$ (plus $0.05 \%$ Cap$\left.\mathrm{Sil}^{\circledR}\right)$. Half of the plants in this experiment were irrigated daily and the other half had water withheld for $5 \mathrm{~d}$ before being rewa-

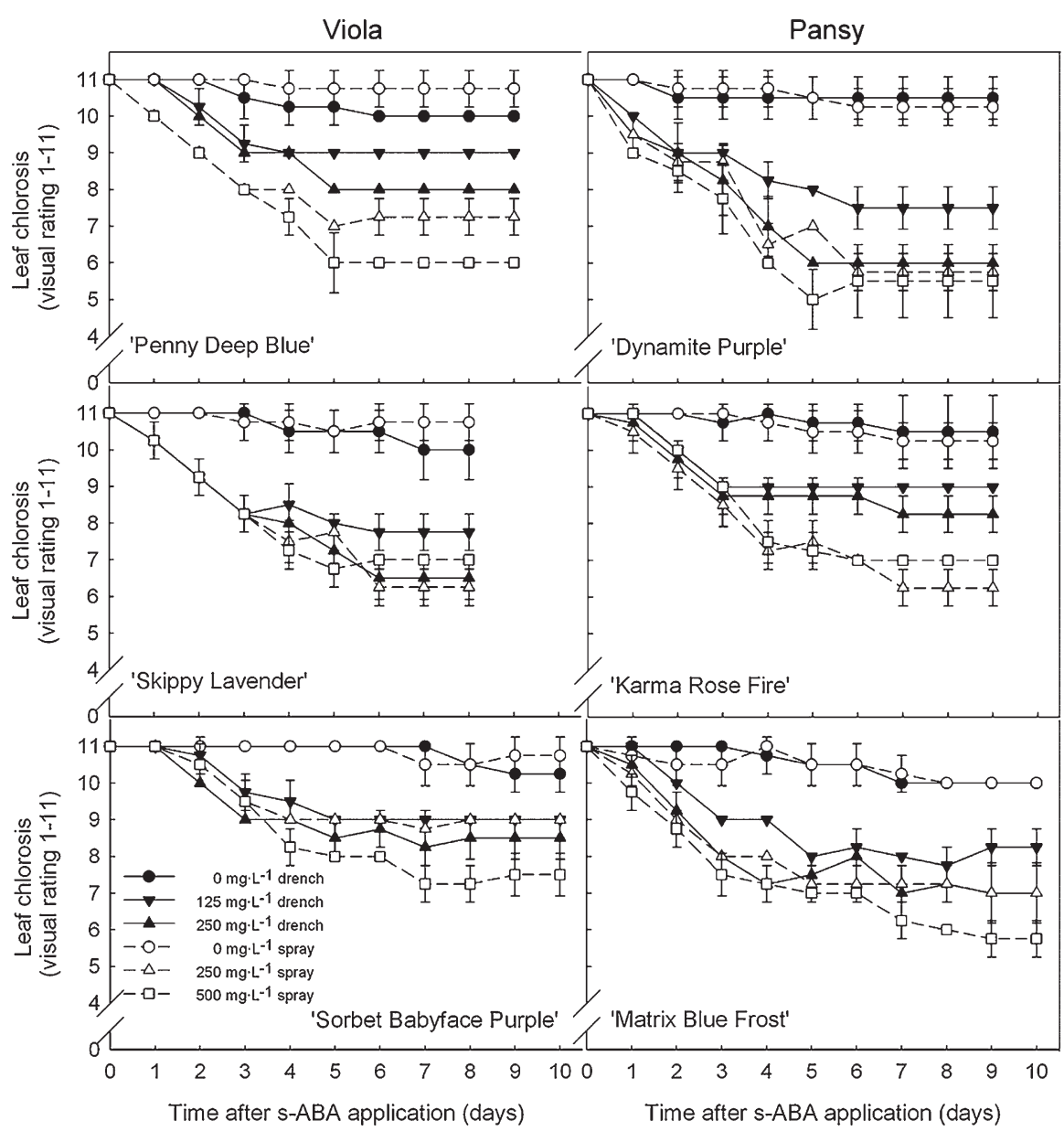

Fig. 2. Leaf chlorosis ratings of finished 11-cm Viola cornuta (viola) and Viola $\times$ wittrockiana (pansy) after a drench or spray application of s-abscisic acid (s-ABA). Finished plants were irrigated daily with 100 $\mathrm{mg} \mathrm{N} / \mathrm{L}$. Leaf chlorosis ratings for the whole plant were from 1 to $11: 11=$ completely green with no sign of chlorosis, $10=10 \%$ or less leaf chlorosis, $9=11 \%$ to $20 \%, 8=21 \%$ to $30 \%, 7=31 \%$ to $40 \%, 6=$ $41 \%$ to $50 \%, 5=51 \%$ to $60 \%, 4=61 \%$ to $70 \%, 3=71 \%$ to $80 \%, 2=81 \%$ to $90 \%$, and $1=91 \%$ to $100 \%$ leaf chlorosis. Visual ratings were recorded daily with Day 0 observations taken just before (1 to $2 \mathrm{~h}$ ) $\mathrm{s}-\mathrm{ABA}$ application. Values are means $\pm \mathrm{SD}$ of four replications $(\mathrm{n}=4)$.

tered. Chlorophyll changes in the leaves were quantified with a chlorophyll content meter (SPAD-502; Konica Minolta Sensing, Inc., Osaka, Japan). The lowest basal leaf on each plant was measured at $5 \mathrm{~d}$ after s-ABA application on both drought-stressed and watered plants.

Expt. 3: s-abscisic acid treatment of pansy and viola plugs. Viola 'Penny Deep Blue', viola 'Skippy Lavender', pansy 'Dynamite 
Purple', and pansy 'Karma Rose Fire' plugs were received in 512-cell trays $\left(5.4 \mathrm{~cm}^{3} /\right.$ cell $)$ and viola 'Sorbet Yellow Delight' and pansy 'Matrix Blue Frost' were in 288-cell trays (7 $\mathrm{cm}^{3} /$ cell). Plugs were randomly assigned to empty plug trays with equal spacing among all replicates and treatments. All plugs were grown and evaluated in the greenhouse under natural irradiance with supplemental lighting (as stated previously) and an average $P P F$ of $250 \mu \mathrm{mol} \cdot \mathrm{m}^{-2} \cdot \mathrm{s}^{-1}$ from 0700 to $1900 \mathrm{HR}$ daily $(\mathrm{DLI}=11.6)$. Mean greenhouse temperatures were $23.4 / 16.7{ }^{\circ} \mathrm{C} \pm 1.2 / 3.7$ day/night with a daytime relative humidity of $49.5 \% \pm 8.5 \%$. Five-week-old pansy and viola plugs were treated on 9 Apr. or 18 Apr. 2008 for initial determination of s-ABA effectiveness and leaf chlorosis. Plugs were sprenched (spray to drench, $\approx 43 \mathrm{~mL}$ per tray) with $0,75,125$, 250,500 , or $1000 \mathrm{mg} \cdot \mathrm{L}^{-1} \mathrm{~s}-\mathrm{ABA}$ (plus $0.05 \%$ $\left.\mathrm{CapSil}^{\circledR}\right)$. Half of the plugs had water withheld for $2 \mathrm{~d}$ and were then rewatered. The other half were irrigated daily throughout the experiment with $100 \mathrm{mg} \mathrm{N} / \mathrm{L}$.

Expt. 4: Application of benzyladenine + gibberellic acid and s-abscisic acid on pansy and viola plugs. Viola 'Penny Deep Blue', viola 'Sorbet Yellow Delight', pansy 'Dynamite Purple' and pansy 'Karma Rose Fire' plugs were received in 288-cell trays $\left(7 \mathrm{~cm}^{3} /\right.$ cell). Replications and treatments were randomly assigned to empty plug trays as described for Expt. 3. Nine-week-old plugs were treated with $\mathrm{BA}+\mathrm{GA}_{4+7}$ before s-ABA application. Treatments began on 8 Jan. 2010 and plugs were grown and evaluated under the greenhouse conditions described previously. The average $P P F$ during this experiment was $269 \mu \mathrm{mol} \cdot \mathrm{m}^{-2} \cdot \mathrm{s}^{-1}$ from 0700 to $1800 \mathrm{HR}$ daily $(\mathrm{DLI}=11.6)$. Mean greenhouse temperatures were $21.9 / 15.6{ }^{\circ} \mathrm{C}$ $\pm 1.1 / 0.9$ day/night with a daytime relative humidity of $29.0 \% \pm 8.1 \%$. Plugs were sprenched $(\approx 29 \mathrm{~mL}$ per tray) with 0 and $5 \mathrm{mg} \cdot \mathrm{L}^{-1} \mathrm{BA}+\mathrm{GA}_{4+7} 12 \mathrm{~h}$ before an application of 0 or $1000 \mathrm{mg} \cdot \mathrm{L}^{-1} \mathrm{~s}-\mathrm{ABA}$ (plus $0.05 \% \mathrm{CapSil}^{\circledR}$ ). All plugs were irrigated daily with $100 \mathrm{mg} \mathrm{N} / \mathrm{L}$.

\section{Evaluations of wilt status and leaf chlorosis}

Visual observations of wilt status and leaf chlorosis were taken daily for all plugs and finished plants. Day 0 was the day of s-ABA treatment. All observations on Day -1 or Day 0 were made just before ( 1 to $2 \mathrm{~h}$ ) the application of PGRs. Wilt status ratings were from 1 to $5: 5=$ completely turgid, $4=$ soft to touch but still upright, $3=$ starting to wilt and no longer upright, 2 = wilted with complete loss of turgor, and $1=$ wilted to the point that leaves are dry and desiccated. The shelf life of drought-stressed plants was calculated as the number of days that it took plants to reach a wilt status rating of 3 or less, after which they were considered unmarketable. Leaf chlorosis ratings for the whole plant were from 1 to 11: $11=$ completely green with no sign of chlorosis, $10=10 \%$ or less leaf chlorosis, $9=11 \%$ to $20 \%, 8=21 \%$ to $30 \%, 7=31 \%$ to $40 \%, 6=41 \%$ to $50 \%, 5$

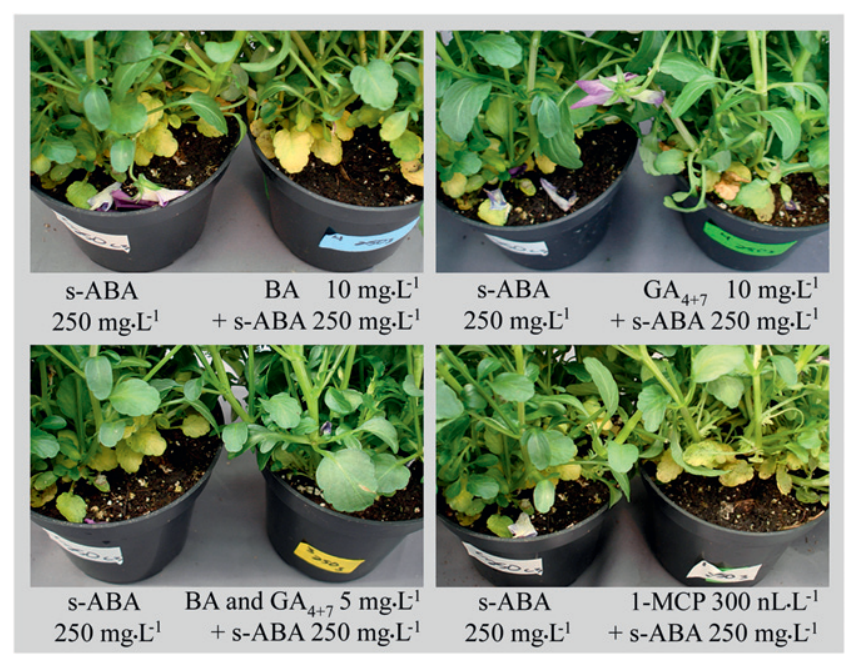

Fig. 3. Viola cornuta (viola) and Viola $\times$ wittrockiana (pansy) treated with other plant growth regulators (PGRs) to prevent s-abscisic acid (s-ABA)-induced leaf chlorosis. Violas and pansies were pretreated with benzyladenine (BA), gibberellic acid $\left(\mathrm{GA}_{4+7}\right), \mathrm{BA}+\mathrm{GA}_{4+7}$, or 1-methylcyclopropene (1-MCP). $\mathrm{BA}, \mathrm{GA}_{4+7}$, and $\mathrm{BA}+\mathrm{GA}_{4+7}$ were applied at the rate of 5 or $10 \mathrm{mg} \cdot \mathrm{L}^{-1}$. Plants were treated with 300 $\mathrm{nL} \cdot \mathrm{L}^{-1} 1-\mathrm{MCP}$ for $10 \mathrm{~h}$. Plants were treated $12 \mathrm{~h}$ later with drench applications of 0 or $250 \mathrm{mg} \cdot \mathrm{L}^{-1} \mathrm{~s}-\mathrm{ABA}$. Images are of viola 'Sorbet Babyface Purple' and are representative of these experiments. Photos were taken $2 \mathrm{~d}$ after s-ABA application. All plants were irrigated daily with $100 \mathrm{mg} \mathrm{N} / \mathrm{L}$.

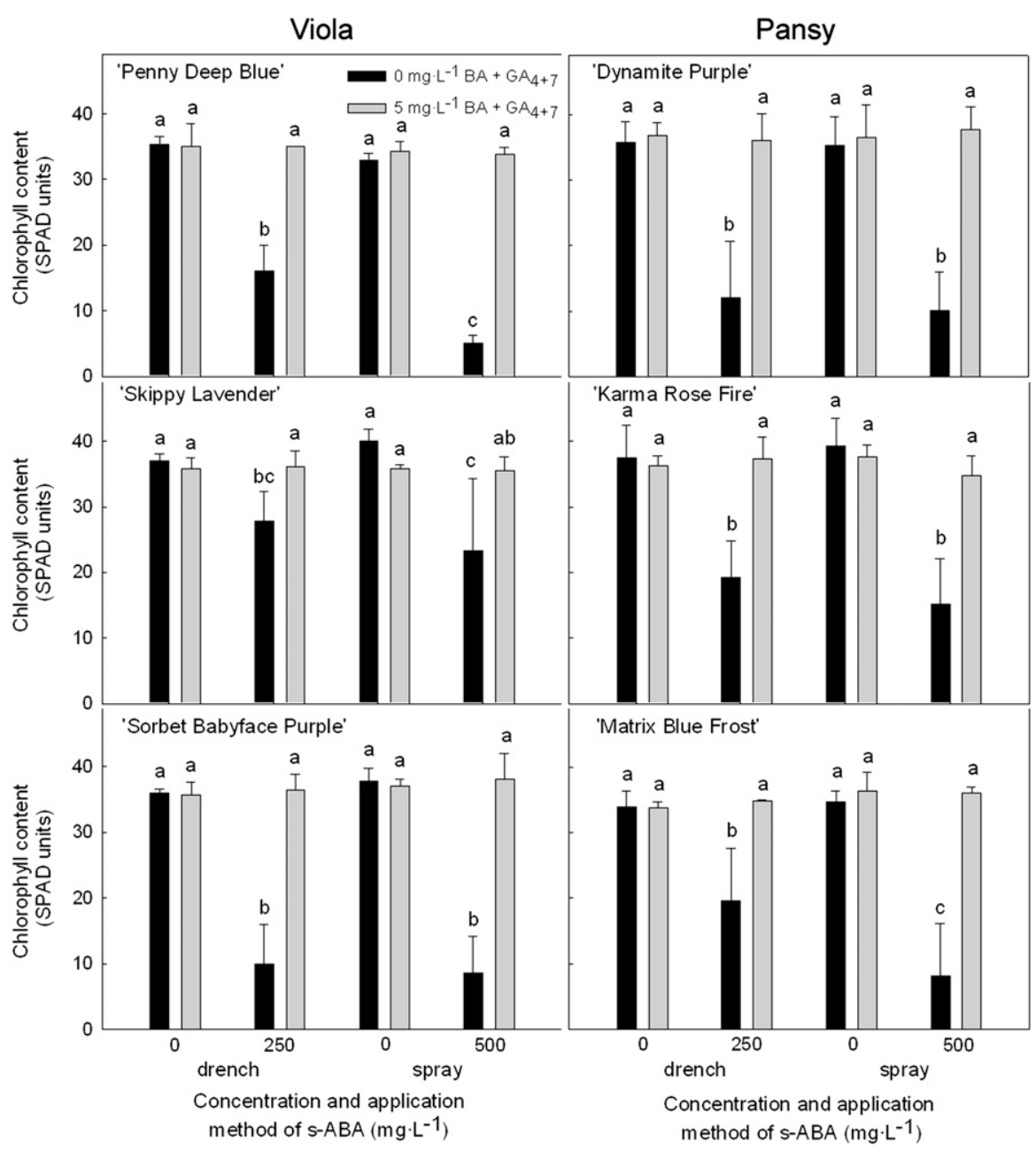

Fig. 4. Chlorophyll content readings of Viola cornuta (viola) and Viola $\times$ wittrockiana (pansy) $5 \mathrm{~d}$ after sabscisic acid (s-ABA) application in watered plants. Finished plants were irrigated daily with $100 \mathrm{mg}$ $\mathrm{N} / \mathrm{L}$. Benzyladenine $(\mathrm{BA})+$ gibberellic acid $\left(\mathrm{GA}_{4+7}\right)\left(0\right.$ or $\left.5 \mathrm{mg} \cdot \mathrm{L}^{-1}\right)$ was applied $12 \mathrm{~h}$ before either a drench $\left(0\right.$ or $\left.250 \mathrm{mg} \cdot \mathrm{L}^{-1}\right)$ or spray $\left(0\right.$ or $\left.500 \mathrm{mg} \cdot \mathrm{L}^{-1}\right)$ application of s-ABA. Data were analyzed using Proc GLM (generalized linear model) with means separated by letters. Values are means \pm SD of four replications $(n=4)$. 
$=51 \%$ to $60 \%, 4=61 \%$ to $70 \%, 3=71 \%$ to $80 \%, 2=81 \%$ to $90 \%$, and $1=91 \%$ to $100 \%$ leaf chlorosis.

\section{Statistical analysis}

Reported values are the means \pm SD of four replications, which is four plants in Expts. 1 and 2. For Expts. 3 and 4, six individual plugs were used as one replication. Data are the average of three replications for pansy 'Matrix Blue Frost' and viola 'Sorbet Yellow Delight' and four replications for all other pansies and violas in Expt. 3. Expt. 4 values are the average of four replications. All experiments were conducted in a completely randomized block design with Expts. 1 and 2 blocked by watering regiment, watered versus water withheld, and by replication. Expts. 3 and 4 were blocked by treatment. All values were analyzed using Proc GLM (generalized linear model) with least significant difference means separation $(P \leq 0.05)$. Values were analyzed by SAS Version 9.1.3 (Statistical Analysis System; SAS Institute, Inc., Cary, NC).

\section{Results}

Expt. 1: Wilt status and shelf life extension in s-abscisic acid-treated $11-\mathrm{cm}$ finished pansies and violas. S-ABA treatments delayed wilting symptoms in drought stressed pansies and violas (Fig. 1; Table 1). Treated plants had increased shelf life compared with control plants $\left(0 \mathrm{mg} \cdot \mathrm{L}^{-1} \mathrm{~s}-\mathrm{ABA}\right)$, and shelf life extensions ranged from 0.5 to $7.7 \mathrm{~d}$ depending on the concentration of s-ABA, method of application, and cultivar (Table 1). The effectiveness of the s-ABA treatment increased at higher concentrations, and differences were observed between cultivars (Fig. 1B; Table 1). Plants treated with $125 \mathrm{mg} \cdot \mathrm{L}^{-1} \mathrm{~s}-\mathrm{ABA}$ were the first to show symptoms of wilting when compared with the 250 or $500-\mathrm{mg} \cdot \mathrm{L}^{-1}$ treatments (Fig. 1B). Application of $500 \mathrm{mg} \cdot \mathrm{L}^{-1} \mathrm{~s}-\mathrm{ABA}$ resulted in the greatest delay in wilting (Fig. 1B) and led to shelf life extensions of 5.0 to $7.7 \mathrm{~d}$ beyond those of the non-ABA-treated controls (Table 1). The longest shelf life extension was observed in pansy 'Dynamite Purple' and the shortest was in viola 'Skippy Lavender'. Three $d$ after rewatering, all the pansies and violas treated with s-ABA recovered from drought stress, but $71 \%$ of control plants (0 mg. $\left.\mathrm{L}^{-1} \mathrm{~s}-\mathrm{ABA}\right)$ died (data not shown).

Expt. 1: Leaf chlorosis of 11-cm finished pansies and violas treated with s-abscisic acid. Although s-ABA was effective at delaying wilting, basal leaf chlorosis was induced in both finished pansies and violas (Figs. 2 and 3). The degree of leaf yellowing was similar in drought-stressed and nonstressed plants (data not shown); therefore, leaf chlorosis was further investigated in watered plants to directly evaluate the effect of sABA applications. Control plants $\left(0 \mathrm{mg} \cdot \mathrm{L}^{-1}\right.$ drench or spray) had little or no leaf chlorosis throughout the experiment (Fig. 2). ABAinduced leaf chlorosis was first observed on Day 1 in pansy 'Dynamite Purple' and viola 'Penny Deep Blue', Day 3 in viola 'Sorbet
Babyface Purple', and Day 2 for all other cultivars (Fig. 2). The severity of leaf chlorosis (as determined by the percentage of the plant that had yellow leaves) continued to increase until Day 5 or later depending on the cultivar. By Day 6, all cultivars treated with $500 \mathrm{mg} \cdot \mathrm{L}^{-1} \mathrm{~s}-\mathrm{ABA}$ (except 'Sorbet Babyface Purple') had a rating of 7 or lower, indicating that $30 \%$ or more of the plant was yellow (Fig. 2).

Expt. 2A: Preventing s-abscisic acidinduced leaf chlorosis with pre-application of other plant growth regulators. Pretreatment with the ethylene perception inhibitor, $1-\mathrm{MCP}$, did not reduce the development of leaf chlorosis in s-ABA-treated plants (Fig. 3). Spray applications of cytokinin (BA at 1 , 2,5 , or $\left.10 \mathrm{mg} \cdot \mathrm{L}^{-1}\right)$ or gibberellins $\left(\mathrm{GA}_{4+7}\right.$ at $1,2,5$, or $10 \mathrm{mg} \cdot \mathrm{L}^{-1}$ ) also did not reduce leaf
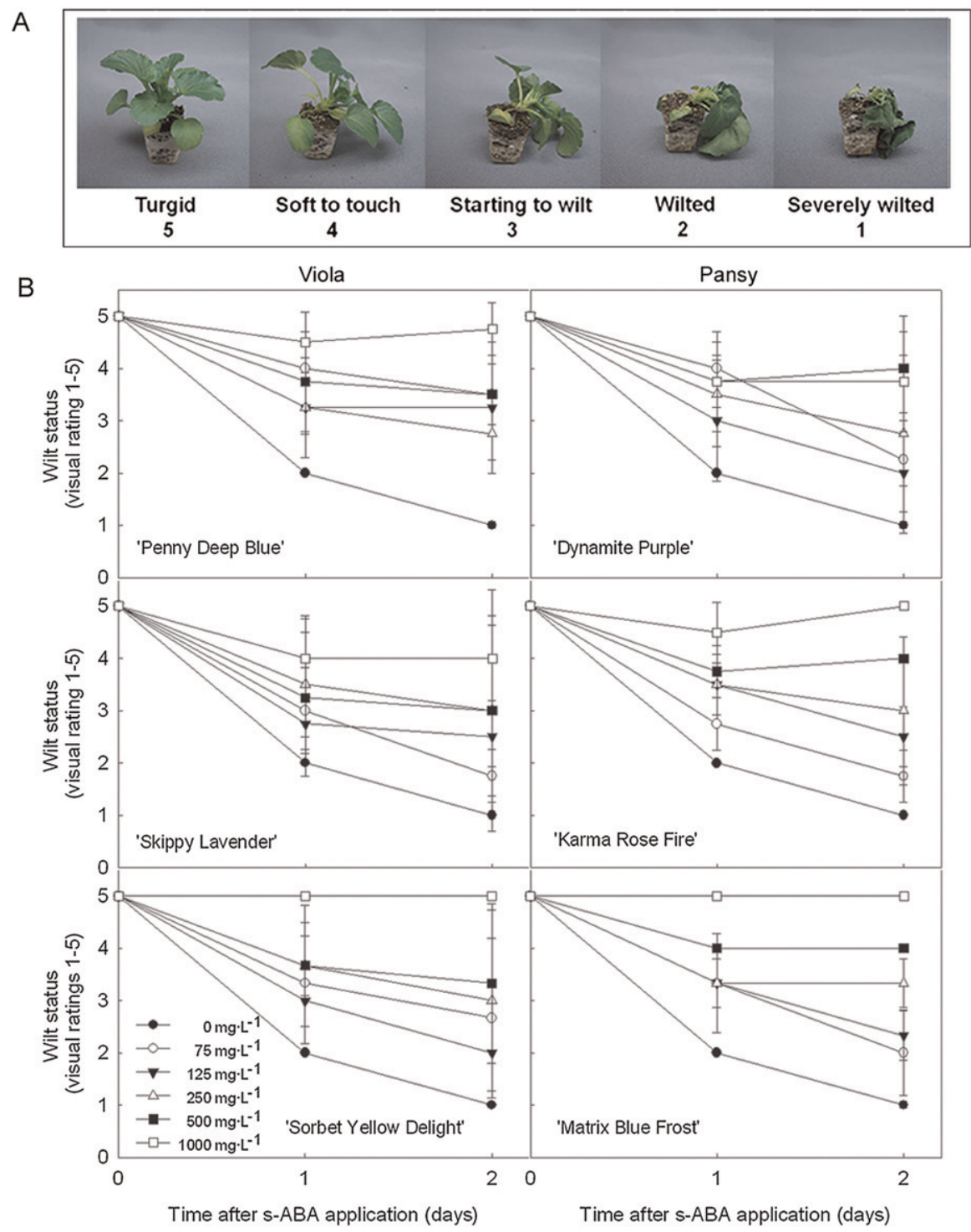

Fig. 5. Wilt status ratings of Viola cornuta (viola) and Viola $\times$ wittrockiana (pansy) plugs after a sprench application of s-abscisic acid (s-ABA) and $2 \mathrm{~d}$ of withholding water. Wilt status ratings were from 1 to 5: $5=$ completely turgid, $4=$ soft to touch but still upright, $3=$ starting to wilt and no longer upright, $2=$ wilted with complete loss of turgor, and $1=$ wilted to the point that leaves are dry and desiccated (A). Visual ratings were taken daily with Day 0 being a completely turgid plug just before ( 1 to $2 \mathrm{~h}$ ) s-ABA application. Values are the mean \pm SD of three replications $(n=3)$ for viola 'Sorbet Yellow Delight' and pansy 'Matrix Blue Frost' and four replications $(\mathrm{n}=4)$ for all other cultivars $(\mathbf{B})$. Each replication consisted of six plugs. 


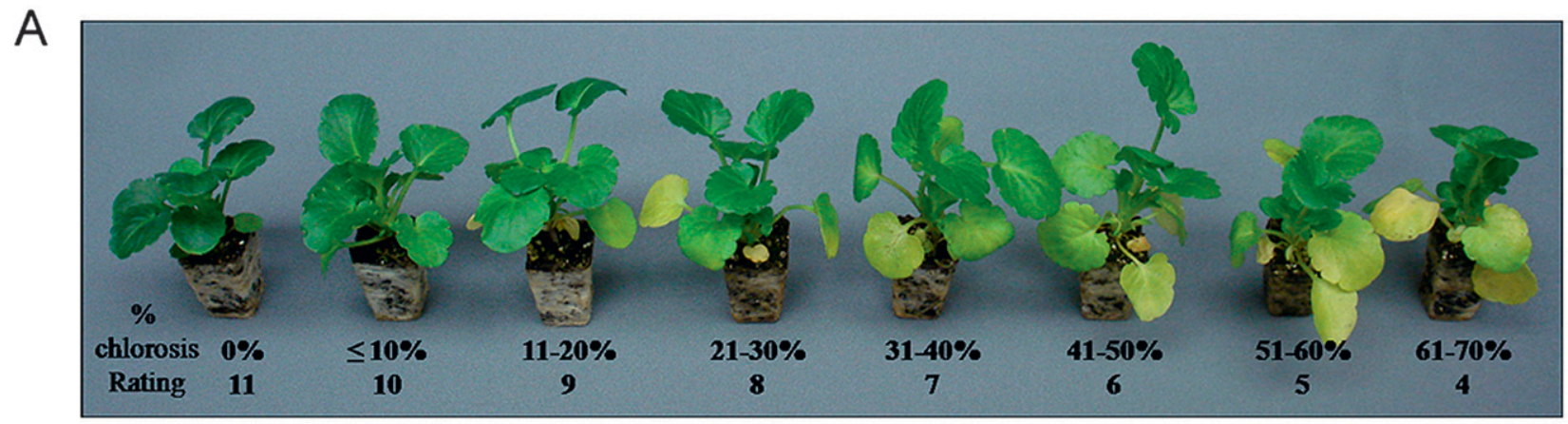

B
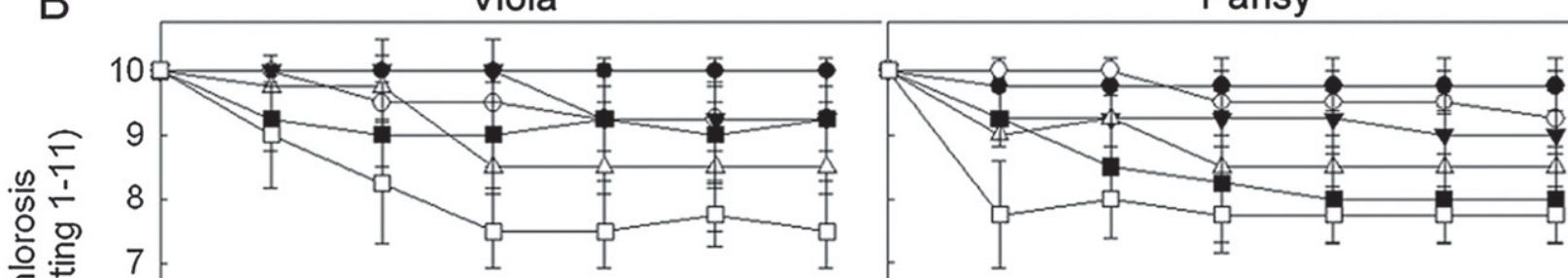

Pansy

은 $\frac{0}{0}$
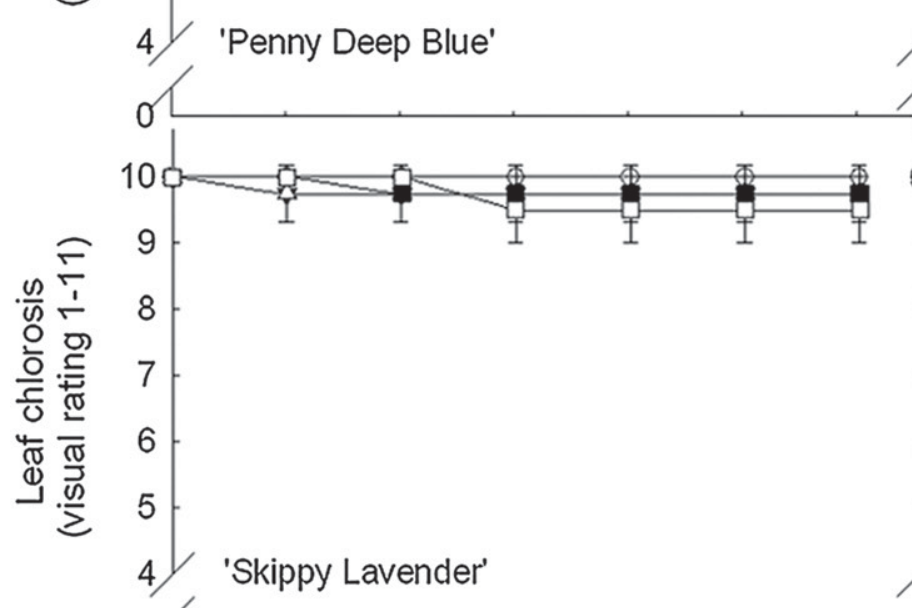

'Dynamite Purple'

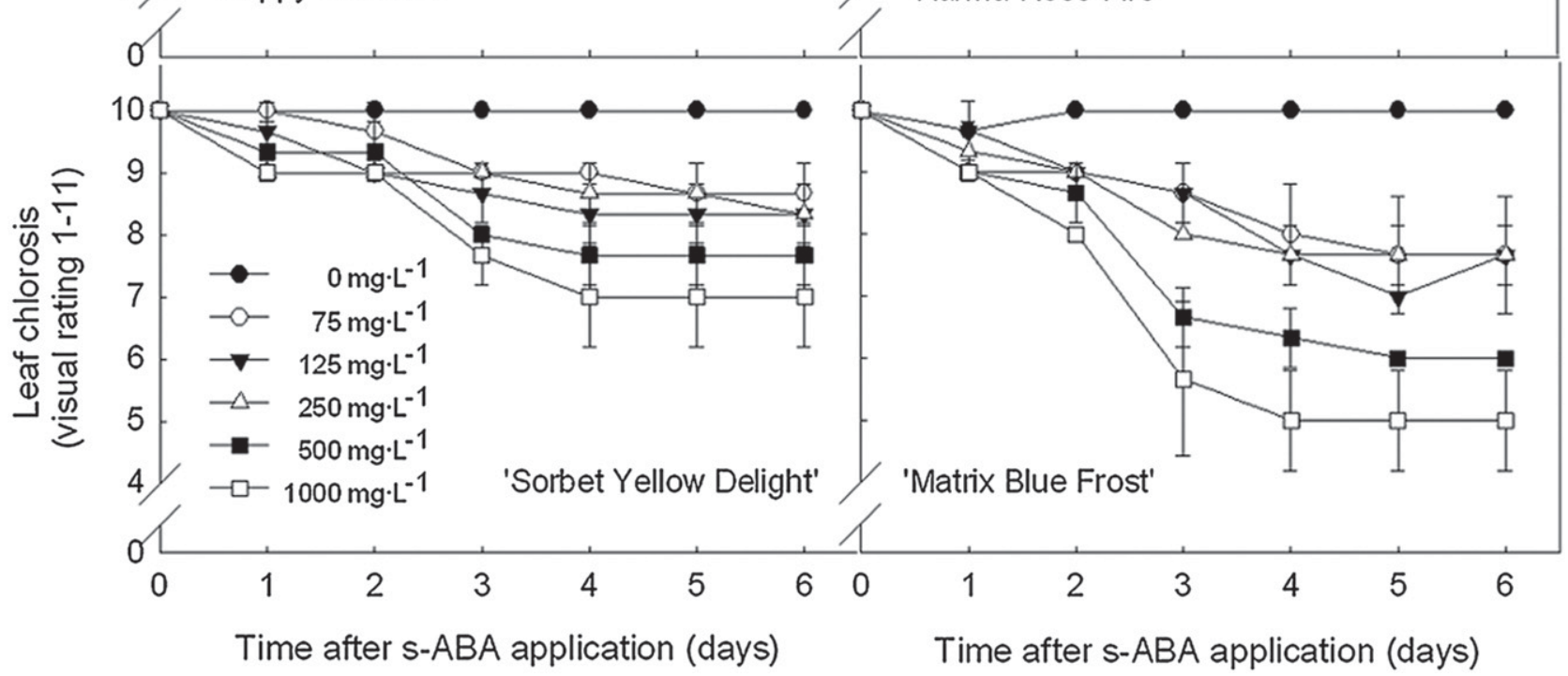

Fig. 6. Leaf chlorosis ratings of Viola cornuta (viola) and Viola $\times$ wittrockiana (pansy) plugs after a sprench application of s-abscisic acid (s-ABA). Plugs were irrigated daily with $100 \mathrm{mg} \mathrm{N} / \mathrm{L}$. Leaf chlorosis ratings for the whole plant were from 1 to $11: 11=$ completely green with no sign of chlorosis, $10=10 \%$ or less leaf chlorosis, $9=11 \%$ to $20 \%, 8=21 \%$ to $30 \%, 7=31 \%$ to $40 \%, 6=41 \%$ to $50 \%, 5=51 \%$ to $60 \%, 4=61 \%$ to $70 \%, 3=71 \%$ to $80 \%, 2=81 \%$ to $90 \%$, and $1=$ $91 \%$ to $100 \%$ leaf chlorosis (A). Visual ratings were recorded daily with Day 0 observations taken just before (1 to $2 \mathrm{~h}$ ) s-ABA application (B). Values are the mean of three replications $(n=3)$ for viola 'Sorbet Yellow Delight' and pansy 'Matrix Blue Frost' or four replications $(n=4) \pm S D$ for all other cultivars $(\mathbf{B})$. Each replication contained six plugs. 

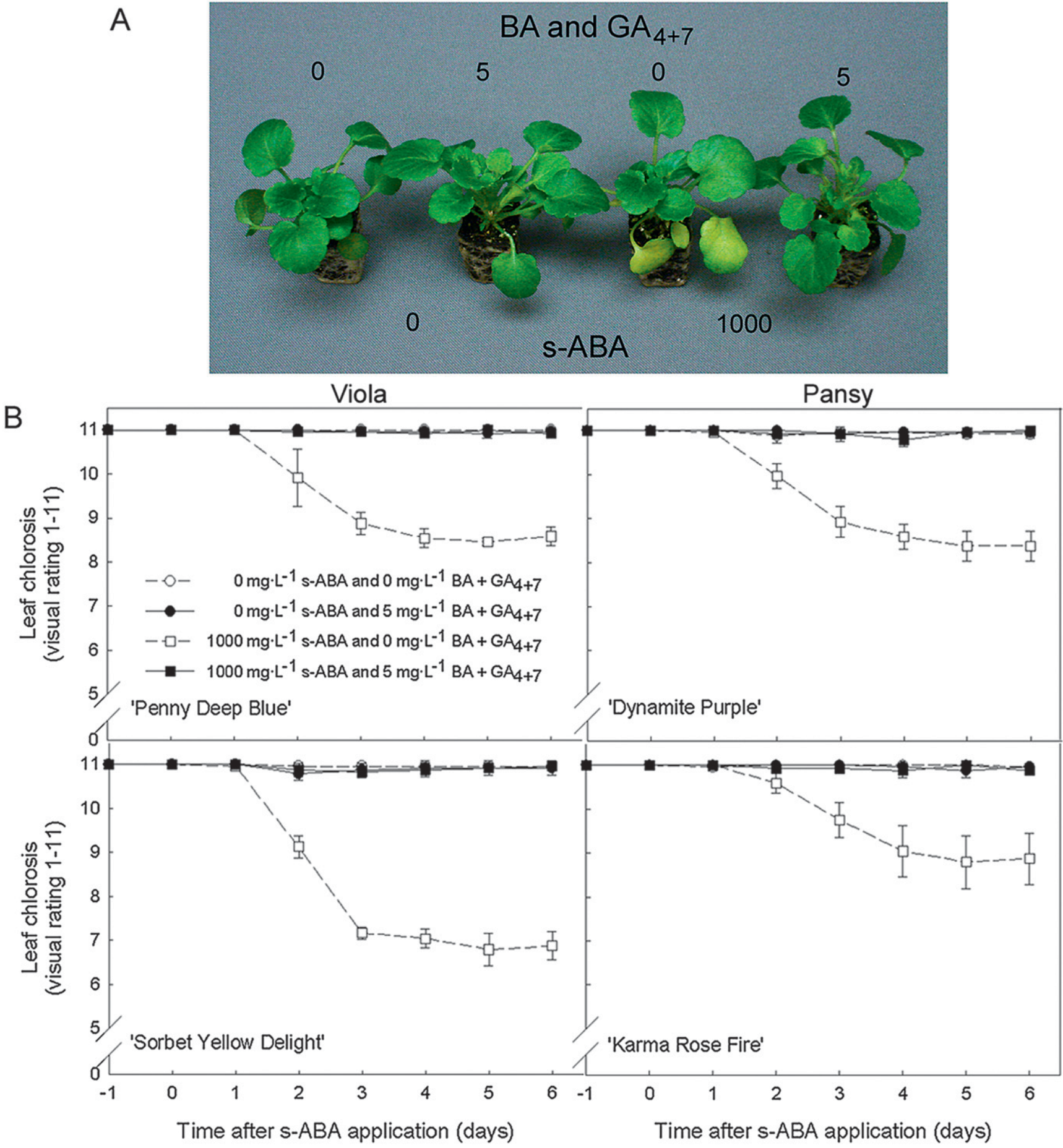

Fig. 7. Visual observations and leaf chlorosis ratings of Viola cornuta (viola) and Viola $\times$ wittrockiana (pansy) plugs after applications of 0 or $5 \mathrm{mg} \cdot \mathrm{L}^{-1}$ benzyladenine (BA) + gibberellic acid $\left(\mathrm{GA}_{4+7}\right)$ and 0 or $1000 \mathrm{mg} \cdot \mathrm{L}^{-1} \mathrm{~s}$-abscisic acid (s-ABA). Images are of viola 'Sorbet Yellow Delight' $3 \mathrm{~d}$ after s-ABA application (A). Plugs were irrigated daily with $100 \mathrm{mg} \mathrm{N} / \mathrm{L}$. Leaf chlorosis ratings for the whole plant were from 1 to $11: 11=$ completely green with no sign of chlorosis, $10=10 \%$ or less leaf chlorosis, $9=11 \%$ to $20 \%, 8=21 \%$ to $30 \%, 7=31 \%$ to $40 \%, 6=41 \%$ to $50 \%, 5=51 \%$ to $60 \%, 4=61 \%$ to $70 \%, 3=71 \%$ to $80 \%, 2=81 \%$ to $90 \%$, and 1 $=91 \%$ to $100 \%$ leaf chlorosis (B). Visual ratings were taken daily. Day -1 was immediately before $(1$ to $2 \mathrm{~h}) \mathrm{BA}$ and $\mathrm{GA}_{4+7}$ applications $(\mathbf{B})$. Values are the mean of four replications \pm SD with each replication consisting of six plugs $(n=4)$ for all pansies and violas $(\mathbf{B})$.

the chlorophyll content of leaves at $5 \mathrm{~d}$ after s-ABA application was the same as non-sABA-treated controls (Fig. 4).

Expt. 3: Wilt status of pansy and viola plugs treated with s-abscisic acid. Sprench applications of s-ABA delayed visible wilting in drought-stressed pansy and viola plugs. One d after withholding water, control plugs (0 $\left.\mathrm{mg} \cdot \mathrm{L}^{-1} \mathrm{~s}-\mathrm{ABA}\right)$ were more wilted than all
s-ABA treatments (Fig. 5B). All control plugs were severely wilted and had reached a wilt status rating of 1 by Day 2. The 1000 $\mathrm{mg} \cdot \mathrm{L}^{-1} \mathrm{~s}$-ABA-treated plugs remained turgid longer than all other treatments. Plugs of pansy 'Matrix Blue Frost' and viola 'Sorbet Yellow Delight' treated with $1000 \mathrm{mg} \cdot \mathrm{L}^{-1}$ s-ABA did not show any wilting symptoms when water was withheld for $2 \mathrm{~d}$. Concen- trations of $75,125,250$, and $500 \mathrm{mg} \cdot \mathrm{L}^{-1}$ of s-ABA were equally effective at preventing wilting, except in pansy 'Dynamite Purple' in which $500 \mathrm{mg} \cdot \mathrm{L}^{-1}$ was as effective as 1000 $\mathrm{mg} \cdot \mathrm{L}^{-1}$ (Fig. 5B). Plugs were rewatered after they had been drought-stressed for $2 \mathrm{~d}$. The survival rate of rewatered plugs was dependent on the concentration of s-ABA. With s-ABA sprench applications of 75, 125, 250, 
500 , and $1000 \mathrm{mg} \cdot \mathrm{L}^{-1}$, pansy plugs had survival rates of $53.7 \%, 40.7 \%, 81.9 \%, 81.0 \%$, and $95.8 \%$, respectively, and viola plugs had survival rates of $49.1 \%, 56.5 \%, 75.0 \%, 75.0 \%$, and $100 \%$, respectively. The survival rate in all the control ( $\left.0 \mathrm{mg} \cdot \mathrm{L}^{-1} \mathrm{~s}-\mathrm{ABA}\right)$ plugs was $0 \%$ after rewatering (data not shown).

Expt. 3: Leaf chlorosis of pansy and viola plugs treated with s-abscisic acid. Watered plugs that were treated with s-ABA developed lower leaf chlorosis similar to what was observed on 11-cm finished plants (Fig. 6). In some instances, this leaf chlorosis was less severe at the plug stage. ABA-induced leaf chlorosis was observed on five of the six cultivars by Day 1 (Fig. 6B). On Day 3, viola 'Sorbet Yellow Delight' and pansy 'Matrix Blue Frost' had more severe leaf chlorosis at higher concentrations of s-ABA (500 and $\left.1000 \mathrm{mg} \cdot \mathrm{L}^{-1}\right)$ compared with the lower concentrations $\left(75,125\right.$, and $\left.250 \mathrm{mg} \cdot \mathrm{L}^{-1}\right)$ (Fig. 6B). Applications of s-ABA did not induce leaf yellowing in viola 'Skippy Lavender', whereas the most severe symptoms were observed in pansy 'Matrix Blue Frost' (Fig. 6B). Similar leaf chlorosis symptoms were observed in drought-stressed plugs after sABA application (data not shown).

Expt. 4: Preventing s-abscisic acidinduced leaf chlorosis with pre-applications of benzyladenine + gibberellic acid in pansy and viola plugs. Pansy and viola plugs sprenched with $1000 \mathrm{mg} \cdot \mathrm{L}^{-1} \mathrm{~s}-\mathrm{ABA}$ and $0 \mathrm{mg} \cdot \mathrm{L}^{-1} \mathrm{BA}+\mathrm{GA}_{4+7}$ developed leaf chlorosis $2 \mathrm{~d}$ after application (Fig. 7). Pretreatment with $5 \mathrm{mg} \cdot \mathrm{L}^{-1} \mathrm{BA}+\mathrm{GA}_{4+7}$ prevented the development of leaf chlorosis on all plugs that received $1000 \mathrm{mg} \cdot \mathrm{L}^{-1} \mathrm{~s}-\mathrm{ABA}$ (Fig. 7). All $\mathrm{BA}+\mathrm{GA}_{4+7}$-treated plugs were visually indistinguishable from the control plugs $(0$ $\mathrm{mg} \cdot \mathrm{L}^{-1} \mathrm{~s}-\mathrm{ABA}$ plus $\left.0 \mathrm{mg} \cdot \mathrm{L}^{-1} \mathrm{BA}+\mathrm{GA}_{4+7}\right)$ (Fig. 7).

\section{Discussion}

All applications of s-ABA regardless of cultivar, developmental stage, method of application, or concentration were effective at delaying wilting symptoms in pansies and violas exposed to severe drought stress. However, we were unable to identify a combination of method of application and concentration of s-ABA that would effectively enhance drought tolerance in any of these plants without inducing leaf chlorosis. Leaf chlorosis in general was less severe in young plants (plugs) than in finished plants that were flowering. s-ABA-treated viola 'Skippy Lavender' developed little or no leaf chlorosis at the plug stage, but finished plants had $20 \%$ to $50 \%$ leaf chlorosis (leaf chlorosis rating of 8 to 6 ) depending on the s-ABA treatment. This indicates that responses to s-ABA will be highly dependent on both cultivar and developmental stage. Plant responses to PGRs are known to vary based on both of these factors (Gent and McAvoy, 2000).

A plant's response to hormones is controlled by both the hormone concentration and the exposure time. In pansies and violas, higher concentrations of s-ABA resulted in more severe symptoms of leaf chlorosis. These exogenous applications can also increase or decrease the endogenous production of other plant hormones and alter tissue sensitivity to hormones. In some plants, exogenous ABA applications stimulate ethylene production (Sharp et al., 2000; Zhang et al., 2009). Ethylene is a gaseous plant hormone known to regulate leaf and flower senescence, and it has been associated with postproduction/postharvest leaf chlorosis and senescence in a variety of crops (Blankenship and Dole, 2003; Bleecker and Kende, 2000). Leaf senescence and abscission in ethylenesensitive crops can be prevented by treatment with the ethylene perception inhibitor, 1MCP (Blankenship and Dole, 2003; Celikel et al., 2002). In some species, including Easter lilies (Lilium longiflorum), leaf senescence is not associated with ethylene production and it is prevented by the application of BA and/or $\mathrm{GA}_{4+7}$ (Franco and Han, 1997). In our experiment, 1-MCP did not prevent sABA-induced leaf chlorosis, indicating that ethylene may not be associated with leaf senescence in pansy and viola.

The application of PGRs that include cytokinins or gibberellins reduces or prevents leaf yellowing in a number of species. Cytokinins such as BA delay the development of leaf yellowing in a variety of floriculture crops, including lilies (Lilium sp.), tulips (Tulipa gesneriana), geraniums, gerbera daisy (Gerbera jamesonii), goldenrod (Solidago canadensis), zinnia (Zinnia elegans), and miniature roses (Rosa $\times$ hybrida) (Franco and Han, 1997; Kim and Miller, 2009; Padhye and Runkle, 2008; Philosoph-Hadas et al., 1996; Pinto et al., 2005; Tjosvold et al., 1994). The application of only gibberellic acid, specifically $\mathrm{GA}_{4+7}$, also effectively enhances postproduction quality by reducing the occurrence of leaf chlorosis and senescence. Basal leaf yellowing is reduced or prevented by $\mathrm{GA}_{4+7}$ application in Easter and Oriental (Lilium sp.) lilies (Han, 1997; Ranwala and Miller, 2000; Ranwala et al., 2000, 2003). Neither BA nor $\mathrm{GA}_{4+7}$ alone was effective at preventing, or even reducing, the s-ABA-induced leaf chlorosis that we observed in pansy and viola.

PGR applications that included a combination of both cytokinins and gibberellic acids $\left(\mathrm{BA}+\mathrm{GA}_{4+7}\right)$ were the only treatment that effectively reduced s-ABA-induced leaf chlorosis. The application of PGRs that contain both BA and $\mathrm{GA}_{4+7}$ also prevent postproduction cold-induced leaf chlorosis and senescence in many species of lilies, including potted Easter lilies, potted Oriental lilies (Lilium sp. 'Stargazer'), and cut Asiatic and Oriental lilies (Lilium sp.) (Funnell and Heins, 1998; Han, 1995, 1997, 2001; Ranwala and Miller, 1998, 2005; Ranwala et al., 2000, 2003; Whitman et al., 2001). Postproduction leaf yellowing in tulips is reduced after the application of BA and $\mathrm{GA}_{4+7}$ (Kim and Miller, 2009). It remains unclear why BA + $\mathrm{GA}_{4+7}$ are effective in combination but not individually in these species.
Application of $\mathrm{BA}+\mathrm{GA}_{4+7}$ before the application of s-ABA could be used by growers to prevent leaf chlorosis. One potential problem with using $\mathrm{BA}+\mathrm{GA}_{4+7}$ to reduce $\mathrm{s}-\mathrm{ABA}$-induced leaf chlorosis is increased internode elongation. The exogenous application of GA independently or in combination with cytokinins results in increased stem elongation in some species, including poinsettia (Euphorbia pulcherrima) and Easter lily (Blanchard and Runkle, 2008; Han, 2000; Ranwala et al., 2003; Ranwala and Miller, 1999; Whitman et al., 2001). In Easter lilies, undesirable stem elongation was minimized by determining the optimum concentration of $\mathrm{GA}_{4+7}$ and using only foliar spray applications (Ranwala et al., 2003). At 21 $\mathrm{d}$ after treatment, we did not measure any differences in plant height resulting from $\mathrm{BA}+\mathrm{GA}_{4+7}$ applications (data not shown). Under our experimental conditions, the low concentrations of GA did not induce stem elongation in violas or pansies. Nineteen of 20 cultivars of tulips treated with $\mathrm{BA}+\mathrm{GA}_{4+7}$ also displayed no stem elongation (Kim and Miller, 2009). The pre-application of a PGR that contains low concentrations of $\mathrm{BA}+\mathrm{GA}_{4+7}$ provides a simple and practical way for growers to effectively use s-ABA to delay visual symptoms of wilting in drought-stressed crops without inducing leaf chlorosis.

\section{Literature Cited}

Armitage, A.M. 1993. Bedding plants: Prolonging shelf performance: Postproduction care and handling. Ball Publ. Co., Batavia, IL.

Barrett, J. and C. Campbell. 2006. S-ABA: Developing a new tool for the big grower. Big Grower 1:26-29.

Blanchard, M.G., L.A. Newton, E.S. Runkle, D. Woolard, and C.A. Campbell. 2007. Exogenous applications of abscisic acid improved the postharvest drought tolerance of several annual bedding plants. Acta Hort. 755:127-132.

Blanchard, M.G. and E.S. Runkle. 2008. Increasing stem elongation and bract size of poinsettia 'Freedom Red' with gibberellins and benzyladenine. Acta Hort. 774:209-215.

Blankenship, S.M. and J.M. Dole. 2003. 1Methylcyclopropene: A review. Postharvest Biol. Technol. 28:1-25.

Bleecker, A.B. and H. Kende. 2000. Ethylene: A gaseous signal molecule in plants. Annu. Rev. Cell Dev. Biol. 16:1-18.

Celikel, F.G., L.L. Dodge, and M.S. Reid. 2002. Efficacy of 1-MCP (1-methylcyclopropene) and Promalin for extending the post-harvest life of Oriental lilies (Lilium $\times$ 'Mona Lisa' and 'Stargazer'). Sci. Hort. 93:149-155.

Clark, D.G., C. Dervinis, J.E. Barrett, H. Klee, and M. Jones. 2004. Drought-induced leaf senescence and horticultural performance of transgenic $\mathrm{P}_{\mathrm{SAG} 12-I P T}$ petunias. J. Amer. Soc. Hort. Sci. 129:93-99.

Franco, R.E. and S.S. Han. 1997. Respiratory changes associated with growth-regulator-delayed leaf yellowing in Easter lily. J. Amer. Soc. Hort. Sci. 122:117-121

Funnell, K.A. and R.D. Heins. 1998. Plant growth regulators reduce postproduction leaf yellowing of potted Asiflorum lilies. HortScience 33:1036-1037. 
Gan, S. and R.M. Amasino. 1995. Inhibition of leaf senescence by autoregulated production of cytokinin. Science 270:1986-1988.

Gan, S. and R.M. Amasino. 1997. Making sense of senescence: Molecular genetic regulation and manipulation of leaf senescence. Plant Physiol. 113:313-319.

Gent, M.P.N. and R.J. McAvoy. 2000. Plant growth retardants in ornamental horticulture: A critical appraisal, p. 89-145. In: Basra, A.S. (ed.). Plant growth regulators in agriculture and horticulture: Their role and commercial uses. The Haworth Press, Inc., Binghamton, NY.

Han, S.S. 1995. Growth regulators delay foliar chlorosis of Easter lily leaves. J. Amer. Soc. Hort. Sci. 120:254-258.

Han, S.S. 1997. Preventing postproduction leaf yellowing in Easter lily. J. Amer. Soc. Hort. Sci. 122:869-872.

Han, S.S. 2000. Growth regulators reduce leaf yellowing in Easter lily caused by close spacing and root rot. HortScience 35:657-660.

Han, S.S. 2001. Benzyladenine and gibberellins improve postharvest quality of cut Asiatic and Oriental lilies. HortScience 36:741-745.

Healy, W. 2009. Piles of money. GrowerTalks Mag. 72:42-46.

Huang, D., W. Wu, S.R. Abrams, and A.J. Cutler. 2008. The relationship of drought-related gene expression in Arabidopsis thaliana to hormonal and environmental factors. J. Expt. Bot. 59: 2991-3007.

Kim, H.-J. and W.B. Miller. 2009. GA $4+7$ plus BA enhances postproduction quality in pot tulips. Postharvest Biol. Technol. 51:272-277.

Kim, J. and M.W. van Iersel. 2008. ABA drenches induce stomatal closure and prolong shelf life of Salvia splendens. Southern Nursery Assn. Res. Conf. 53:107-111.

Malladi, A. and J.K. Burns. 2007. Communication by plant growth regulators in roots and shoots of horticultural crops. HortScience 42:11131117.

Monteiro, J.A., T.A. Nell, and J.E. Barrett. 2001. Postproduction of potted miniature rose:
Flower respiration and single flower longevity. J. Amer. Soc. Hort. Sci. 126:134-139.

Nilsen, E.T. and D.M. Orcutte. 1996. Phytohormones and plant responses to stress, p. 83-198. In: Nilsen, E.T. and D.M. Orcutte (eds.). The physiology of plants under stress, abiotic factors. John Wiley and Sons, New York, NY.

Padhye, S. and E. Runkle. 2008. The influence of benzyladenine alone or with gibberellic acid on inhibition of postharvest leaf chlorosis of potted geranium, miniature rose, and gerbera daisy. HortScience 43:1149 (abstr.).

Philosoph-Hadas, S., R. Michaeli, Y. Reuveni, and S. Meir. 1996. Benzyladenine pulsing retards leaf yellowing and improves quality of goldenrod (Solidago canadensis) cut flowers. Postharvest Biol. Technol. 9:65-73.

Pinto, A.C.R., T.J.D. Rodrigues, and J.C. Barbosa. 2005. Benzyladenine sprays and senescent flowers removal on postproduction performance of potted Zinnia 'Profusion Cherry'. Acta Hort. 683:391-398.

Ranwala, A.P., G. Legnani, and W.B. Miller. 2003. Minimizing stem elongation during spray applications of gibberellins ${ }_{4+7}$ and benzyladenine to prevent leaf chlorosis in Easter lilies. HortScience 38:1210-1213.

Ranwala, A.P. and W.B. Miller. 1998. Gibberellin $_{4+7}$, benzyladenine, and supplemental light improve postharvest leaf and flower quality of cold-stored 'Stargazer' hybrid lilies. J. Amer. Soc. Hort. Sci. 123:563-568.

Ranwala, A.P. and W.B. Miller. 1999. Timing of gibberellins $_{4+7}+$ benzyladenine sprays influences efficacy against foliar chlorosis and plant height in Easter lily. HortScience 34:902-903.

Ranwala, A.P. and W.B. Miller. 2000. Preventive mechanisms of gibberellin $_{4+7}$ and light on lowtemperature-induced leaf senescence in Lilium cv. Stargazer. Postharvest Biol. Tech. 19:85-92.

Ranwala, A.P. and W.B. Miller. 2005. Effects of cold storage on postharvest leaf and flower quality of potted Oriental-, Asiatic- and LA-hybrid lily cultivars. Scientia Hort. 105: 383-392.
Ranwala, A.P., W.B. Miller, T.I. Kirk, and P.A. Hammer. 2000. Ancymidol drenches, reversed greenhouse temperatures, postgreenhouse cold storage, and hormone sprays affect postharvest leaf chlorosis in Easter lily. J. Amer. Soc. Hort. Sci. 125:248-253.

SAS Institute, Inc. 2002-2003. SAS/STAT TM user's guide. Version 9.1.3. SAS Institute, Inc., Cary, NC.

Sharma, N., S.R. Abrams, and D.R. Waterer. 2005. Uptake, movement, activity, and persistence of an abscisic acid analog (8' acetylene ABA methylester) in marigold and tomato. J. Plant Growth Regul. 24:28-35.

Sharma, N., S.R. Abrams, and D.R. Waterer. 2006. Evaluation of abscisic acid analogs as holding agents for bedding plant seedlings. HortTechnology 16:71-77.

Sharp, R.E., M.E. LeNoble, M.A. Else, E.T Thorne, and F. Gherardi. 2000. Endogenous ABA maintains shoot growth in tomato independently of effects on plant water balance: Evidence for an interaction with ethylene. J. Expt. Bot. 51:1575-1584.

Tjosvold, S.A., M.-J. Wu, and M.S. Reid. 1994. Reduction of postproduction quality loss in potted miniature roses. HortScience 29:293-294.

Vardi, Y. and S. Mayak. 1989. Involvement of abscisic acid during water stress and recovery in petunia flowers. Acta Hort. 261:107-112.

Waterland, N.L., C.A. Campbell, J.J. Finer, and M.L. Jones. 2010. Abscisic acid application enhances drought stress tolerance in bedding plants. HortScience 45:409-413.

Whitman, C.M., R.D. Heins, R. Moe, and K.A. Funnell. 2001. $\mathrm{GA}_{4+7}$ plus benzyladenine reduce foliar chlorosis of Lilium longiflorum. Sci. Hort. 89:143-154.

Zacarias, L. and M.S. Reid. 1990. Role of growth regulators in the senescence of Arabidopsis thaliana leaves. Physiol. Plant. 80:549-554.

Zhang, M., B. Yuan, and P. Leng. 2009. The role of ABA in triggering ethylene biosynthesis and ripening of tomato fruit. J. Expt. Bot. 60:15791588 . 